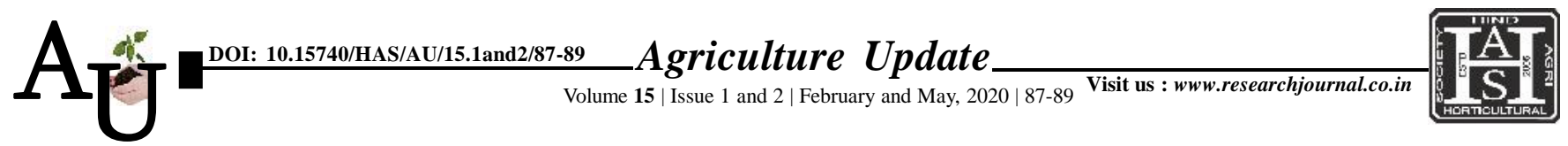

ISSN-0973-1520

\title{
Research article: Front line demonstrations in greengram in Visakhapatnam district of Andhra Pradesh
}

\author{
P.B. Pradeep Kumar and K. Tejeswara Rao
}

Article Chronicle:

Received :

26.03.2020;

Revised :

13.04.2020;

Accepted :

21.04.2020

KeY Words :

SUMMARY : The study was conducted at Visakhapatnam district of Andhra Pradesh on FLD in greengram by Scientists of district Agricultural Advisory and Transfer of Technology Centre of ANGRAU. Greengram crop was sown as rice fallow in Rabi season during 2018-19 and 2019-20 in an area of 1803 ha and 2739 ha also it was found in an increase in yield of 35.4 per cent and 38.7 per cent in FLD field, respectively. Thus, it was concluded that front line demonstrations conducted under the close supervision of scientists is one of the most important tools of extension to demonstrate crop management practices at farmers' field. FLDs motivate farmers to adopt scientific practices. So, FLDs are to be designed, supervised with extension activities viz., training programmes, demonstration, field days etc. to increase yields and profits of farmers.

How to cite this article : Pradeep Kumar, P.B. and Rao, K. Tejeswara (2020). Front line demonstrations in greengram in Visakhapatnam district of Andhra Pradesh. Agric. Update, 15(1 and 2): 87-89; DOI : 10.15740/ HAS/AU/15.1and2/87-89. Copyright@ 2020: Hind Agri-Horticultural Society.

Greengram, Yield,

FLD, Cost of

cultivation

Author for correspondence :

P.B. Pradeep Kumar District Agricultural Advisory and Transfer of Technology Centre (ANGRAU), Kondempudi, Visakhapatnam (A.P.)

India

Email:pradeepagrico@

yahoo.com

See end of the article for authors' affiliations 